Article

\title{
Sport Education and Traditional Teaching: Influence on Students' Empowerment and Self-Confidence in High School Physical Education Classes
}

\author{
Cristiana Bessa ${ }^{1, * \mathbb{C}}$, Peter Hastie ${ }^{2} \mathbb{D}$, António Rosado $^{3} \mathbb{D}$ and Isabel Mesquita ${ }^{1}$ \\ 1 Centre for Research, Education, Innovation and Intervention in Sport (CIFI2D), Faculty of Sport, University of \\ Porto, 4200-450 Porto, Portugal; imesquita@fade.up.pt \\ 2 School of Kinesiology, Auburn University, Auburn, AL 36849-0001, USA; hastipe@auburn.edu \\ 3 Faculty of Human Kinetics, University of Lisbon, 1495-751 Cruz Quebrada, Lisbon, Portugal; \\ arosado@fmh.ulisboa.pt \\ * Correspondence: cbessa@fade.up.pt
}

check for

updates

Citation: Bessa, C.; Hastie, P.;

Rosado, A.; Mesquita, I. Sport

Education and Traditional Teaching:

Influence on Students' Empowerment and Self-Confidence in High School

Physical Education Classes.

Sustainability 2021, 13, 578.

https://doi.org/10.3390/su13020578

Received: 17 December 2020

Accepted: 6 January 2021

Published: 9 January 2021

Publisher's Note: MDPI stays neutral with regard to jurisdictional clai$\mathrm{ms}$ in published maps and institutional affiliations.

Copyright: $(\odot 2021$ by the authors. Licensee MDPI, Basel, Switzerland. This article is an open access article distributed under the terms and conditions of the Creative Commons Attribution (CC BY) license (https:// creativecommons.org/licenses/by/ $4.0 /)$.

\begin{abstract}
Physical Education (PE) is recognized for its value in developing personal and social development. However, the instructional approach adopted by the teacher may affect the achievement of positive outcomes. This study aimed to examine the effects of two different teaching approaches, Traditional Teaching (TT) and the Sport Education (SE) model, on students' empowerment and self-confidence in high school PE classes. A total of 430 high-school students ( $66.7 \%$ male), aged $14-21$ years $(M=16.22, S D=1.03)$ enrolled in 10th, 11th and 12th grades, participated in this study. A pretest-posttest quasi-experimental design was used across 18 classes. Classes met two times a week during a period of 8 weeks for a total of $1080 \mathrm{~min}$. The Psychological Empowerment Instrument was used to measure empowerment. Students' self-confidence was measured with the self-confidence sub-scale of the Competitive State Anxiety Inventory-2. The findings of the research revealed that only SE was effective in improving high school students' empowerment and self-confidence. In the TT group, no gains were found, even decreasing over time. These results reinforce the adequacy of SE in PE as a curricular model to be used by teachers, particularly for the development of students' empowerment and self-confidence.
\end{abstract}

Keywords: teaching approaches; skills development; personal and social skills; preservice teachers

\section{Introduction}

We live in a constantly changing world, and adaptability is a skill that everyone needs. In the school context, the ever-changing society calls for teachers to be more responsive to students' needs, supporting them to more successfully meet life's challenges [1,2]. Here, educational policies and curriculum guidelines emphasize the students' personal and social development as a fundamental goal of contemporary education. In particular, Physical Education (PE) is recognized for its value in developing positive attitudes and values that contribute to students' personal and social development [3,4]. Nevertheless, evidence suggests that simple participation in PE classes does not automatically lead to positive outcomes [5,6]. It may or may not positively influence the development of students' personal and social skills [7,8]. Rather, it is requested that there is an empowering education that prepares and supports students to succeed in dynamic and collaborative work environments, where cooperation, self-direction, self-confidence, and communication are key competencies [9]. Therefore, it is necessary to create pedagogical environments and circumstances that promote students working collaboratively, cohesively, and constructively, through which positive outcomes can be encouraged and acquired [10]. Examples of those pedagogies include cooperative learning [11], experiential learning [12], and problembased learning [13]. 
It is noted that the pedagogies valued in the development of students' personal and social skills, such as empowerment and self-confidence, go against the predominant form of instruction in PE. Traditionally, a teacher-centered approach (TCA) is adopted, which involves a teaching style where decisions about planning, instruction, and assessment are all made by teachers [14]. For the purposes of this paper, that approach has been given the label of "traditional teaching" (TT), largely because it has been the predominant form of instruction across the past 50 years [15]. In TT, a major concern is the transfer of knowledge, relating to elementary motor skills and techniques within a highly structured lesson [16]. Consequently, students are required to be attentive, disciplined and well-behaved, put all their focus on the teacher, and assume a passive, receptive and reproductive role $[17,18]$. These features fail to promote social processes where decision making and problem-solving are valued, and by consequence are not particularly conducive to personal and social development [19]. Several key authors in physical education have noted this as a major limitation of TT [20-22].

That being said, early research on the impact of TT provided evidence of its effectiveness in improving students' skill performance (especially in early ages and less complex skills) $[16,23,24]$, through high rates of positive and corrective feedback [22]. However, research also showed that such a controlling teaching style tends to thwart students' feelings of competence, autonomy and relatedness [25]. Beyond that, its decontextualized sports teaching [26], and its emphasis on a mechanistic and "one-size-fits-all" pedagogical approach has shown that TT is not the most appropriate for the contemporary educational demands [27].

By consequence, alternatives to the TCA were developed during the 1990s educational reform, and were based on constructivist and social learning theories [28], which are considered to be a more student-centered approach (SCA). Several noted scholars in PE introduced alternatives to the TT approach by introducing what Ennis [20] called "second generation of models", such as Sport Education (SE) [21], Teaching Games for Understanding [29], or Teaching Personal and Social Responsibility [30]. This new trend moved the focus from the teacher and instruction to the student and learning [22], with the aim of providing opportunities to promote students' cognitive development, ability to make decisions, as well as problem solving. Therefore, a change in the roles of both teachers and students is noted. Teachers act as facilitators, giving students an active role in building their knowledge autonomously, competently, and responsibly. Students are encouraged to make choices about what to learn and how to learn [20,31,32].

In PE, SE [21] is one of the most widely implemented and researched model. SE structure and pedagogies focus on transferable skills, knowledge, and behaviours and values, providing richer and more complete experiences than typical PE approaches [33]. This model aims to provide an authentic and contextualized sporting experience looking for help students to develop as competent, literate, and enthusiastic sportspersons [33,34]. In this sense, SE incorporates six features: seasons, affiliation, formal competition, culminating events, record keeping, and festivity. To better achieve it, SE integrates cooperative smallgroup work and peer teaching, students have the opportunity to engage in a variety of roles beyond simply that of player (such as coaches, referees, scorekeepers, statisticians, or sports director). Within these roles, students have the chance to make decisions and are encouraged to learn committedly, autonomously, and responsibly [35].

Over the years, SE has been a growing body of research in PE. Findings support the positive and significant outcomes on participants' game performance and tacticaltechnical knowledge [36], on their personal skills and social skills such as responsibility, satisfaction, empathy, or affiliation [37]. However, concerning students' personal and social development, there is still a need for further empirical evidence comparing and showing the impact of different curriculum models, particularly with respect to two important, but underdeveloped variables, namely empowerment and self-confidence.

For the purposes of this paper, empowerment has been defined as a process through which people gain autonomy and self-determination to achieve their own goals, and 
represent their interests, becoming stronger and more confident [38]. Self-confidence refers to individuals' beliefs that they can accomplish a given task or achieve a desired objective [39].

Empowerment and self-confidence show themselves to be closely linked concepts to learning. If students feel empowered and confident to act, they will likely learn in the process, be more able to engage in challenges and opportunities, and experience a greater ability to take control or to make changes in their own lives. Particularly, PE has the potential to promote and develop personal qualities and experiences essential to increase students' empowerment and self-confidence [40].

Although it has been recognized that variables such as empowerment and selfconfidence are important goals of education [41], and that PE can be a medium of these variables $[42,43]$, few studies were conducted in this scope.

In the specific case of SE, it is believed that by providing students with decision-making opportunities and encouraging them to solve problems on their own, they can develop a sense of feeling in control which reinforces their sense of empowerment. Consequently, this control is associated with positive and successful experiences, which can boost their self-confidence $[40,44]$. The scarce results corroborate the positive impact of a SE season on students' empowerment given the opportunities to students to solve problems and make decisions [45-47]. Evidence also suggests that students develop self-confidence through participation in a SE season due to opportunities to take on roles that encourage them to talk with their peers and make collective decisions [48,49].

Research comparing SE and TT tends to analyze the differences between both models on the motor and cognitive domains (e.g., physical activity, content knowledge, and technical and game performance), and its impact on the development of personal and social skills [50]. In this respect, comparisons between SE and TT have focused more on the constructs of autonomy (e.g., [51]), motivation (e.g., [52]), and enjoyment (e.g., [53]), all of which show superior results when students experience a season of SE. In essence then, the teaching styles of SE tend to be particularly autonomy supportive [54-56], while those adopted in the comparison TT conditions reflect more closely to controlling styles.

To the best of our knowledge, the impact of a SE season and a more traditional unit in developing student's empowerment and self-confidence has not been directly measured or compared in previous research. Rather, they are part of a set of outputs obtained through the perceptions of students or teachers about the instructional models (e.g., $[46,47,49])$.

Furthermore, most of the comparative studies between TT and SE, as well as studies focusing on the personal and social skills within SE reported in the literature, have involved experienced teachers as the instructors $[37,57]$. Recognizing that research indicates that preservice teachers (PSTs) points out some difficulties in applying different teaching models [58,59], it is relevant to develop studies with PSTs that gives them training experiences likely to challenge them to use different pedagogies and fill possible gaps, both in content knowledge and in pedagogy strategies. Consequently, it sets the stage for PSTs' ability and motivation to implement different teaching models in the future [60].

For specific learning outcomes, optimal learning environments need to be designed [22]. There is still a lack of controlled comparisons between TT and SE in promoting empowerment and self-confidence as personal and core learning outcomes, and still more involving PSTs. It is an opportunity to challenge PSTs and to inform the physical education teacher education (PETE) programs, seeking to optimize the process of learning to teach PE [61,62]. The use of classes taught by PSTs allows knowing whether PSTs are using each teaching approach appropriately, and understanding if their students perceive any differences between teaching approaches.

Furthermore, research on this topic allows the dissemination of relevant data that shows the strengths of different approaches to the development of students' engagement and responsibility. Indeed, this study may contribute to overcoming potential barriers to the implementation of different PE teaching approaches, such as resistance within some PE departments or in-service teachers' own beliefs and habits [63]. 
Aligned with the aforementioned, this study aimed to examine the effects of the two different teaching approaches (TT or SE), on students' empowerment and self-confidence, in high school PE classes. It was hypothesized that students' empowerment and selfconfidence would be significantly greater following SE than TT (Hypothesis 1). Furthermore, it was hypothesized that students' empowerment and self-confidence would significantly improve only for those in the SE classes (Hypothesis 2), with no such improvements within classes taught using the TT (Hypothesis 3).

\section{Materials and Methods}

\subsection{Participants and Setting}

A total of 430 high-school students $(66.7 \%$ male) in 8 schools in northern Portugal took part in the study. The sample was composed of 224 girls and 206 boys and ranged in age from 14 to 21 years $(\mathrm{M}=16.22, \mathrm{SD}=1.03)$. These students were in grades $10(n=199$; 8 classes), 11 ( $n=181 ; 8$ classes), and 12 ( $n=50 ; 2$ classes).

The 18 PSTs (12 male and 6 female) involved in this study were in the final year of their master's degree program in "Teaching of Physical Education in Primary and Secondary Education" at a large public university in northern Portugal. In the previous year of their coursework, all PSTs had completed practical experiences as learners across several PE content areas, and had experience with both teacher and student-centered approaches. The PSTs also had experience teaching TT and SE lessons during the previous year of their coursework. Furthermore, during their student teaching, the PSTs taught full versions of the models under the supervision of experienced teachers who were familiar with each approach and model. All PSTs had previously taught units of TT and SE with the same classes, as this study was conducted during the third term of the school year. For this study, the PSTs only taught one of the two conditions (TT or SE) to their class.

The ethics committee of the first author's university approved the protocol of the study, and all participants provided assent following parental informed consent.

\subsection{Design}

The study design was a quasi-experimental pretest-posttest, used across 18 classes from 8 different schools. Pretests took place in the first lesson, while posttests took place at the last lesson of the unit.

Two hundred and forty lessons across ten different classes at 6 schools were taught using the TT approach, while 192 lessons across 8 different classes were taught at 6 schools following the key principles of SE. All classes were co-educational and met twice a week over a period of 8 weeks (one lesson was scheduled for $45 \mathrm{~min}$ and the other for $90 \mathrm{~min}$ ). This total instruction time of 1080 min easily exceeded the recommended minimum of 800 posited by Siedentop et al. (2011) as necessary for a fully-fledged experience of SE at the secondary level.

\subsubsection{Description of the Units}

Table 1 shows the list of schools, model, seasons/units, grades, and participants.

Traditional Teaching

Ten TT units were completed across 6 schools and involved a total of 226 students from 10 different classes. The TT unit was characterized by teacher-controlled decisions and teacher-directed engagement patterns for students. The PST was responsible for the main managerial control: established the learning content, implemented class warm-ups, defined the patterns of the technique model, controlled the rhythm of the tasks, as well as the engaged time in the exercises and transition between activities. The PST delivered positive and corrective feedback to students frequently. Lessons began with basic skill drills to game play, with practice organized in lines of students providing high rates of practice and repetition. In the final part of each lesson, students chose teams to compete against each other (students had different teammates each lesson). The last three lessons were 
solely dedicated to competition between teams, organized by the PST. All record-keeping was conducted by the teacher. No formal statistics were kept. Students were engaged in whole-class instruction and were not responsible for roles such as refereeing and scoring.

Table 1. List of schools, model, seasons/units, grade, and participants.

\begin{tabular}{|c|c|c|c|c|c|}
\hline School & PST & Model & Grade & Students & Sport Played \\
\hline \multirow{3}{*}{ A } & 1 female & SE & 10 & $\begin{array}{l}10 \text { Boys } \\
16 \text { Girls }\end{array}$ & Track and field \\
\hline & 1 female & TT & 10 & $\begin{array}{l}15 \text { Boys } \\
10 \text { Girls }\end{array}$ & Track and field \\
\hline & 1 male & TT & 10 & $\begin{array}{l}21 \text { Boys } \\
2 \text { Girls }\end{array}$ & Track and field \\
\hline \multirow{3}{*}{ B } & 1 male & SE & 10 & $\begin{array}{l}10 \text { Boys } \\
19 \text { Girls }\end{array}$ & Volleyball \\
\hline & 1 male & TT & 11 & $\begin{array}{l}19 \text { Boys } \\
5 \text { Girls }\end{array}$ & Volleyball \\
\hline & 1 male & TT & 11 & $\begin{array}{l}19 \text { Boys } \\
5 \text { Girls }\end{array}$ & Football \\
\hline C & 1 female & TT & 11 & $\begin{array}{c}7 \text { Boys } \\
13 \text { Girls }\end{array}$ & Basketball \\
\hline \multirow{3}{*}{ D } & 1 female & TT & 11 & $\begin{array}{l}11 \text { Boys } \\
11 \text { Girls }\end{array}$ & Basketball \\
\hline & 1 male & TT & 10 & $\begin{array}{c}5 \text { Boys } \\
14 \text { Girls }\end{array}$ & Volleyball \\
\hline & 1 male & SE & 10 & $\begin{array}{l}12 \text { Boys } \\
14 \text { Girls }\end{array}$ & Volleyball \\
\hline \multirow{3}{*}{ E } & 1 male & TT & 12 & $\begin{array}{c}3 \text { Boys } \\
19 \text { Girls }\end{array}$ & Basketball \\
\hline & 1 male & SE & 11 & $\begin{array}{l}10 \text { Boys } \\
15 \text { Girls }\end{array}$ & Gymnastics \\
\hline & 1 male & TT & 12 & $\begin{array}{l}16 \text { Boys } \\
12 \text { Girls }\end{array}$ & Basketball \\
\hline \multirow{2}{*}{$\mathrm{F}$} & 1 male & SE & 10 & $\begin{array}{l}16 \text { Boys } \\
9 \text { Girls }\end{array}$ & Rugby \\
\hline & 1 female & SE & 10 & $\begin{array}{l}12 \text { Boys } \\
14 \text { Girls }\end{array}$ & Rugby \\
\hline G & 1 male & TT & 11 & $\begin{array}{l}11 \text { Boys } \\
7 \text { Girls }\end{array}$ & Gymnastics \\
\hline \multirow[t]{2}{*}{$\mathrm{H}$} & 1 female & SE & 11 & $\begin{array}{l}10 \text { Boys } \\
14 \text { Girls }\end{array}$ & Gymnastics \\
\hline & 1 male & $\mathrm{SE}$ & 11 & $\begin{array}{c}5 \text { Boys } \\
18 \text { Girls }\end{array}$ & Gymnastics \\
\hline
\end{tabular}

Note: School names are pseudonyms.

\section{Sport Education}

The SE seasons followed the six key characteristics described by Siedentop and Tannehill [64] to ensure the most authentic experience. These are seasons, affiliation, formal competition, record keeping, festivity, and a culminating event.

In the initial lessons (1-2), the PST presented the model, described the roles, and explained the competition format. Equally skilled teams were created by the PST, following the criterion of homogeneity in gender and level of motor ability. These teams were maintained throughout the entirety of the season. After being placed on teams, the students assigned roles, designed colored shirts, and determined their team name. All students practiced different roles (at some point of the season) such as coaching the team, refereeing games, scorekeeping, and keeping team and individual statistics; however, no formal 
statistics were posted. The following four lessons (3-6) were led by the PST for basic skills introduction. In the student-led phase, the lessons began with a warm-up (led by students), practice in the first half, with the second half seeing formal competition. Lessons 7 through to 15 involved teams practicing and competing against each other while learning roles such as referee, scorekeeper, and statistician, while lessons 16 through to 23 were dedicated to a tournament. In these lessons, scores related to fair play were attributed, which were counted towards the final score of each team. The last lesson consisted of a final competition and awards ceremony.

\subsubsection{Validity of Instruction}

A 10-item checklist with benchmarks [65] was used to assess the behavioral fidelity of the PST's instruction according to SE or TT (Table 2). The checklist asks a trained observer to make decisions about whether an item is representative of the lesson. In this case, two experts in instructional models with extensive research in instructional models, examined videotapes of four randomly selected lessons of each class to confirm the characteristics of the model used in the lessons. Analysis across the two experts revealed an inter-observer agreement of $100 \%$, confirming the instructional model used in the lessons.

Table 2. Instructional Checklist [65].

1. Groups of students go to a designated home area and begin warming up with that group.

2. Students warm up as a whole class under the direction of the teacher.

3. Students practice together with their group/team under the direction of a peer leader.

4. Students practice individually or in small groups under the direction of the teacher.

5. Students remain a part of easily identifiable groups throughout the lesson and throughout different tasks.

6. Student grouping throughout the lesson is variable across tasks.

7. Performance records are kept by students.

8. Students perform specialized tasks within their group/team.

9. Student performance scores count toward a formal and public scoring system.

10. Student performance scores are not recorded or are recorded in private.

Note. Items 1, 3, 5, 7, 8, and 9 are characteristics of the SE. Items 2, 4, 6, and 10 are characteristics of the TT.

To be effective, an instructional model needs contextual conditions such as teacher proficiency and student willingness for the model [22].

All PSTs were familiar with both models, having previously taught units/seasons of TT and SE. All PSTs were familiar with both models, having experienced SE and TT as participants during their on-campus coursework, and having taught units/seasons of TT and SE. The SE PSTs also attended a three-hour SE workshop led by an investigator who was familiar with the SE curriculum and the challenges implementing this model in schools.

There was sufficient space and equipment (e.g., balls, scorers, whistles, etc.) in all schools for every class to create adequate pedagogical and practical conditions.

Table 3 provides data confirming the characteristics of the model used in the lessons by each PST.

\subsection{Instruments}

Empowerment. Spreitzer's [66] 12-item Psychological Empowerment Instrument (PEI), translated and adapted for Portuguese populations by Santos et al. [67], was used to measure empowerment. The PEI test and retest reliability has been shown to be strong and the validity estimates for the dimensions are typically around 0.80 (e.g., [68]). The items are distributed by four dimensions: meaning, competence, self-determination, and impact. Meaning reflects the value of a work goal or purpose, judged in relation to an individual's own ideals or standards [69]. Competence, or self-efficacy, reflects an individual's belief in his or her capacity to perform activities with skill [70]. Self-determination reflects autonomy in the initiation and continuation of work behaviors and processes [71]. Impact reflects the degree to which an individual can influence strategic, administrative, or 
operating outcomes at work [72]. Sample items include, "The role that I have in class is very important to me" (meaning); "I am confident with the performance that I have in PE class" (competence); "I have significant autonomy in determining how I do my tasks in PE class" (self-determination); and "I have a great deal of control over what happens in PE class" (impact). All items were measured using a 7-point Likert-type scale that ranged from 1 (totally disagree) to 7 (totally agree).

Table 3. Characteristics of the lessons taught by each PST.

\begin{tabular}{|c|c|c|c|c|c|c|c|c|c|c|c|}
\hline PST & Item 1 & Item 2 & Item 3 & Item 4 & Item 5 & Item 6 & Item 7 & Item 8 & Item 9 & Item 10 & Model \\
\hline A1 & $x$ & & $x$ & & $x$ & & $x$ & $x$ & & & SE \\
\hline A2 & & $x$ & & $x$ & & $x$ & & & & $x$ & TT \\
\hline $\mathrm{A} 3$ & & $X$ & & $X$ & & $x$ & & & & $X$ & TT \\
\hline B1 & $x$ & & $x$ & & $x$ & & $X$ & $X$ & $x$ & & SE \\
\hline B2 & & $X$ & & $X$ & & $X$ & & & & $X$ & TT \\
\hline B3 & & $x$ & & $X$ & & $x$ & & & & $X$ & TT \\
\hline $\mathrm{C} 1$ & & $x$ & & $x$ & & $x$ & & & & $x$ & TT \\
\hline $\mathrm{D} 1$ & & $x$ & & $x$ & & $x$ & & & & $x$ & TT \\
\hline $\mathrm{D} 2$ & & $x$ & & $x$ & & $x$ & & & & $X$ & TT \\
\hline D3 & $x$ & & $x$ & & $x$ & & $x$ & $x$ & $x$ & & SE \\
\hline E1 & & $x$ & & $x$ & & $x$ & & & & $x$ & TT \\
\hline E2 & $x$ & & $x$ & & $x$ & & $x$ & $x$ & & & SE \\
\hline E3 & & $x$ & & $x$ & & $x$ & & & & $x$ & TT \\
\hline $\mathrm{F} 1$ & $x$ & & $x$ & & $x$ & & $x$ & $x$ & $x$ & & SE \\
\hline F2 & $x$ & & $X$ & & $X$ & & $X$ & $X$ & $X$ & & $\mathrm{SE}$ \\
\hline G1 & & $X$ & & $X$ & & $X$ & & & & $X$ & TT \\
\hline $\mathrm{H} 1$ & $x$ & & $x$ & & $x$ & & $x$ & $x$ & $x$ & & SE \\
\hline $\mathrm{H} 2$ & $X$ & & $X$ & & $X$ & & $x$ & $X$ & $X$ & & SE \\
\hline
\end{tabular}

Self-confidence. Self-confidence was measured with the 9-item self-confidence sub-scale of the Competitive State Anxiety Inventory-2 (CSAI-2) [73] translated and adapted for Portuguese populations by Vasconcelos-Raposo [74]. CSAI-2 has been widely used by researchers as a means of explaining the independent forms of influence of somatic anxiety, cognitive anxiety, and self-confidence on sport performance. The validity and reliability of this instrument has been verified by Gabilondo, et al. [75] Sample items include "I feel at ease" and "I feel secure". All items were measured using a 5-point Likert-type scale that ranged from 1 (never) to 5 (always).

Both questionnaires were completed in a classroom setting during school time in the presence of the first author. Average completion time was $10 \mathrm{~min}$. Pre-test data were collected in the first lesson of the unit/season, while post-test data were collected following the last lesson of the unit/season.

\subsection{Data Analysis}

The IBM Statistical Package for the Social Sciences (version 26) was used to analyze the data. The descriptive analysis conducted to characterize the samples revealed nonnormality of the distribution of data. Therefore, non-parametric statistics were used. Scale reliability was obtained for the pre- and post-test using Ordinal alpha for Likert data. Ordinal alpha is conceptually equivalent to Cronbach's alpha and it performs better for ordinal data [76].

The Mann-Whitney test for two independent samples (empowerment and selfconfidence) was used to test the differences between groups in two assessment moments, the pre-test (PreT) and the post-test (PosT). To test intra-group differences from the PreT to the PosT, the Wilcoxon test was applied. When the Wilcoxon's yielded a significant difference, subsequent analyses were performed at the subscale level to provide an insight into the precise location of differences. The effect size was estimated with the $r$ statistic for non-parametric tests [77] using the formula: $r=Z / \sqrt{N}$ where $Z$ represents the $Z$ score resulting from the non-parametric test; and, $N$ to the total number of subjects. According to Cohen [78], a small effect size with $r<0.30$, a moderate effect size with $r$ between 0.31 and 0.50 , and a large effect size with $r>0.50$ were considered. The statistical level to determine the significance was set at $p<0.05$. 


\section{Results}

Tables 4 and 5 present the Ordinal alpha coefficients and descriptive statistics for both conditions and all measures at pre- and post-test. The Ordinal alpha coefficients of all subscales yielded values above 0.70 , which can be considered acceptable [79]. Regarding the descriptive statistics, there are certain changes in means and standard deviations between the pre- and post-test in both groups.

Table 4. Descriptive statistics and internal consistency of subscales for TT context $(n=226)$.

\begin{tabular}{|c|c|c|c|c|c|c|c|c|}
\hline \multirow[b]{2}{*}{ Measure Subscale } & \multicolumn{4}{|c|}{ PRE-TEST } & \multicolumn{4}{|c|}{ POST-TEST } \\
\hline & Ord. $\alpha$ & $\begin{array}{c}M \\
\text { (SD) }\end{array}$ & $\mathbf{M}_{\mathbf{e}}$ & $\begin{array}{l}\text { Ske } \\
\text { Kur }\end{array}$ & Ord. $\alpha$ & $\begin{array}{c}M \\
\text { (SD) }\end{array}$ & $\mathbf{M}_{\mathbf{e}}$ & $\begin{array}{l}\text { Ske } \\
\text { Kur }\end{array}$ \\
\hline \multicolumn{9}{|l|}{ CSAI-2 } \\
\hline Self-confidence & 0.90 & $\begin{array}{c}3.81 \\
(0.04)\end{array}$ & 3.80 & $\begin{array}{l}-0.39 \\
-0.08\end{array}$ & 0.92 & $\begin{array}{c}3.68 \\
(0.05)\end{array}$ & 3.80 & $\begin{array}{l}-0.45 \\
-0.26\end{array}$ \\
\hline SPES & 0.94 & $\begin{array}{c}4.89 \\
(0.06)\end{array}$ & 4.92 & $\begin{array}{c}-0.46 \\
1.39\end{array}$ & 0.97 & $\begin{array}{c}4.86 \\
(0.07)\end{array}$ & 5.00 & $\begin{array}{c}-0.48 \\
0.53\end{array}$ \\
\hline Meaning & 0.85 & $\begin{array}{c}4.86 \\
(0.07)\end{array}$ & 5.00 & $\begin{array}{c}-0.08 \\
0.32\end{array}$ & 0.92 & $\begin{array}{c}4.82 \\
(0.08)\end{array}$ & 5.00 & $\begin{array}{r}-0.33 \\
-0.08\end{array}$ \\
\hline Competence & 0.85 & 5.18 & 5.00 & $\begin{array}{c}-0.55 \\
0.84\end{array}$ & 0.88 & $\begin{array}{c}5.03 \\
(0.07)\end{array}$ & 5.00 & $\begin{array}{c}-0.61 \\
0.85\end{array}$ \\
\hline Self-determination & 0.77 & $\begin{array}{c}4.98 \\
(0.07)\end{array}$ & 5.00 & $\begin{array}{c}-0.68 \\
1.39\end{array}$ & 0.90 & $\begin{array}{c}4.97 \\
(0.08)\end{array}$ & 5.00 & $\begin{array}{c}-0.56 \\
0.52\end{array}$ \\
\hline Impact & 0.72 & $\begin{array}{c}4.55 \\
(0.07)\end{array}$ & 4.67 & $\begin{array}{c}-0.23 \\
0.76\end{array}$ & 0.85 & $\begin{array}{c}4.65 \\
(0.07)\end{array}$ & 4.67 & $\begin{array}{l}-0.26 \\
-0.01\end{array}$ \\
\hline
\end{tabular}

CSAI-2-Competitive State Anxiety Inventory-2; SPES—Spreitzer's Psychological Empowerment Scale.

Table 5. Descriptive statistics and internal consistency of subscales for SE context $(n=204)$.

\begin{tabular}{|c|c|c|c|c|c|c|c|c|}
\hline Measure & \multicolumn{4}{|c|}{ PRE-TEST } & \multicolumn{4}{|c|}{ POST-TEST } \\
\hline Subscale & Ord. $\alpha$ & M (SD) & $\mathbf{M}_{\mathbf{e}}$ & $\begin{array}{l}\text { Ske } \\
\text { Kur }\end{array}$ & Ord. $\alpha$ & $\begin{array}{c}\text { M } \\
\text { (SD) }\end{array}$ & $\mathbf{M}_{\mathbf{e}}$ & $\begin{array}{l}\text { Ske } \\
\text { Kur }\end{array}$ \\
\hline \multicolumn{9}{|l|}{ CSAI-2 } \\
\hline Self-confidence & 0.86 & $\begin{array}{c}3.73 \\
(0.04)\end{array}$ & 3.70 & $\begin{array}{c}0.32 \\
-0.86\end{array}$ & 0.91 & $\begin{array}{c}3.95 \\
(0.05)\end{array}$ & 4.00 & $\begin{array}{c}-0.71 \\
1.10\end{array}$ \\
\hline SPES & 0.94 & $\begin{array}{c}4.76 \\
(0.06)\end{array}$ & 4.75 & $\begin{array}{c}-0.25 \\
0.65\end{array}$ & 0.96 & $\begin{array}{c}5.24 \\
(0.07)\end{array}$ & 5.25 & $\begin{array}{l}-0.21 \\
-0.33\end{array}$ \\
\hline Meaning & 0.87 & $\begin{array}{c}4.58 \\
(0.08)\end{array}$ & 4.67 & $\begin{array}{c}-0.43 \\
0.17\end{array}$ & 0.91 & $\begin{array}{c}5.15 \\
(0.08)\end{array}$ & 5.00 & $\begin{array}{c}-0.45 \\
0.11\end{array}$ \\
\hline Competence & 0.82 & $\begin{array}{c}5.09 \\
(0.07)\end{array}$ & 5.00 & $\begin{array}{l}-0.71 \\
-0.77\end{array}$ & 0.88 & $\begin{array}{c}5.41 \\
(0.07)\end{array}$ & 5.33 & $\begin{array}{l}-0.29 \\
-0.34\end{array}$ \\
\hline Self-determination & 0.72 & $\begin{array}{c}4.99 \\
(0.08)\end{array}$ & 5.00 & $\begin{array}{l}-0.27 \\
-0.07\end{array}$ & 0.85 & $\begin{array}{c}5.35 \\
(0.08)\end{array}$ & 5.33 & $\begin{array}{c}-0.62 \\
0.52\end{array}$ \\
\hline Impact & 0.70 & $\begin{array}{c}4.40 \\
(0.07)\end{array}$ & 4.33 & $\begin{array}{c}-0.26 \\
0.91\end{array}$ & 0.81 & $\begin{array}{c}5.06 \\
(0.08)\end{array}$ & 5.00 & $\begin{array}{l}-0.08 \\
-0.32\end{array}$ \\
\hline
\end{tabular}

In the PreT, initial homogeneity among groups was assessed using the Mann-Whitney test on the dependent variables: self-confidence and empowerment (Table 6). In the PosT, significant differences were found between SE and TT groups on students' perceptions of empowerment $(p=0.001)$, with a small effect size $(r=0.17)$. Moreover, significant differences were found on students' perceptions of self-confidence $(p<0.001)$, with a small effect size $(r=0.18)$.

Table 7 presents the results of the Wilcoxon Rank test used to analyze the differences obtained within groups. Significant pre-post intervention differences were found among the study groups on the examined dependent variables (Table 7). Regarding the SE group, there were considerable improvements on student's perceptions for both variables, empowerment $(p<0.001, r=0.42)$ and self-confidence $(p<0.001, r=0.31)$, from pre- to post-test. No significant differences were found in the perceptions of students in the TT group for any variable. 
Table 6. Results of the intergroup analysis using the Mann-Whitney U test.

\begin{tabular}{ccccccccc}
\hline & \multicolumn{4}{c}{ PRE-TEST } & \multicolumn{3}{c}{ POST-TEST } \\
\hline Measure & IA & $\begin{array}{c}\text { Sum of } \\
\text { Ranks }\end{array}$ & $\begin{array}{c}\text { Z } \\
\text { Scores }\end{array}$ & $p$ & $\begin{array}{c}\text { Sum of } \\
\text { Ranks }\end{array}$ & $\begin{array}{c}\text { Z } \\
\text { Scores }\end{array}$ & $p$ & $r$ \\
\hline CSAI-2 & TT & $51,057.50$ & -1.83 & 0.067 & $\begin{array}{c}43,961.00 \\
48,704.00\end{array}$ & -3.690 & $<0.001$ & 0.18 \\
(Self-confidence subscale) & SE & $41,607.50$ & & & & & \\
\hline SPES & TT & $50,619.50$ & -1.49 & 0.136 & $44,233.50$ & -3.475 & 0.001 & 0.17 \\
& SE & $42,045.50$ & & & $48,431.50$ & & & \\
\hline
\end{tabular}

Table 7. Results of the within analysis using the Wilcoxon test for empowerment and self-confidence across time (Pre- and Post-test results).

\begin{tabular}{ccccc}
\hline Measure & IA & Z Scores & $\boldsymbol{p}$ & $\boldsymbol{r}$ \\
\hline CSAI-2 & TT & -1.697 & 0.090 & 0.11 \\
(Self-confidence subscale) & SE & -4.445 & $<0.001$ & 0.31 \\
\hline \multirow{2}{*}{ SPES } & TT & -0.527 & 0.598 & 0.04 \\
& SE & -5.973 & $<0.001$ & 0.42 \\
\hline
\end{tabular}

Table 8 shows subsequent analyses performed at the empowerment subscale level to provide insight into the precise location of differences. Considering the SE students perceptions, results revealed significant increases on all subscales $(p<0.001)$, presenting a large effect size for impact $(r=0.50)$, and a considerable effect size for meaning $(r=0.40)$, competence $(r=0.26)$, and self-determination $(r=0.26)$.

Table 8. Results of the within analysis using the Wilcoxon test for empowerment subscale (Pre- and Post-test results).

\begin{tabular}{cccccc}
\hline Measure & Subscale & IA & Z Scores & $p$ & $\boldsymbol{r}$ \\
\hline \multirow{4}{*}{ SPES } & Meaning & SE & -5.692 & $<0.001$ & 0.40 \\
& Competence & SE & -3.682 & $<0.001$ & 0.26 \\
& Self-determination & SE & -3.762 & $<0.001$ & 0.26 \\
& Impact & SE & -6.731 & $<0.001$ & 0.50 \\
\hline
\end{tabular}

\section{Discussion and Conclusions}

The purpose of the current study was to examine the effects of the implementation of two different instructional models (SE and TT) by PSTs on students' empowerment and self-confidence in high school PE classes. Results of the present study showed that only SE was effective in improving high school students' empowerment and self-confidence, supporting the first hypothesis. This effectiveness was confirmed by the comparison with the data from the TT group, with significant increases for the SE group in the studied variables. While in the SE group the participants exhibited significant improvements in their empowerment and self-confidence levels, in the TT group, no gains were found, confirming the second and third hypotheses respectively. In fact, in the TT group, the levels of empowerment and self-confidence decreased over time, even though this decrease was not significant. This sort of effect has previously occurred in the Spittle and Byrne [80] study, in which the traditional condition was associated with decreases in student personal and social variables, namely in perceived competence, task orientation, and mastery of climate. According to these authors, these effects may be due partly to high initial levels of motivation. Furthermore, the length of the TT unit may also have contributed to these decreases, since traditionally, this type of PE classes rarely spends so much time on just one sport. If the experience is not being positive and successful, students can become demotivated, compromising their sense of empowerment and self-confidence.

When considering the decrease in the perception of empowerment by students in the TT group, a possible explanation for these results lies in the fact that the PST was responsible 
for making all the decisions (planning, instruction, assessment, students' engagement patterns, etc.), limiting students to a passive and reproductive behavior, with no space to make decisions or solve problems.

On the other hand, the decrease (although not significant) obtained in the students' self-confidence in the TT group, when there is a high frequency of positive feedback from the teacher, is noteworthy. This may be because students have previously experienced other models, namely SE, and eventually could have perceived less opportunities to develop this variable. Furthermore, we also believe that the empowerment results may have influenced this result. That is, if the students do not feel empowered, they do not feel self-confident.

The efficiency of SE in improving students' empowerment and self-confidence lies primarily in the strategies used during the season. Examples are the possibility of assuming particular roles and responsibilities that encourage students to talk and make decisions, the opportunity to have some degree of control over their learning process, and to provide students with opportunities to solve problems and make decisions. In this sense, students can experience boosts to their self-esteem and self-confidence. Likewise, providing students with decision-making opportunities and encouraging them to solve problems on their own may help them feel in control. This can eventually reinforce their sense of ownership and empowerment, both of which are important ingredients in the development of self-confidence.

Concerning the SE gains on the studied variables, similar results have been reported in the investigation of Gil-Arias, Harvey, Cárceles, Práxedes, and Del Villar [45], where in a hybrid TGfU/SE unit, students felt empowered because they were provided with the opportunity to solve specific tactical problems. Likewise, Hastie and Buchanan [46] incorporated throughout a hybrid TGfU/SE unit numerous instances of problem-solving without providing the solution, which they suggested contributed to students' empowerment. Regarding self-confidence, our results are consistent with previous research, which has indicated that the self-confidence enhancing strategies, the supportive learning environment, as well as the performance of different roles used in a SE season, were the key to the positive development of students' self-confidence [48,49].

A review of the research concerning students' development of personal and social skills when participating in PE classes with SE [37] indicates that only $23 \%$ of studies (12 studies) incorporate a comparison with a TT. Of these, only two studies [81,82] had PSTs teaching the PE classes, with both reporting significant improvements. Regarding the effect sizes of the SE season, results of the present study confirmed not only the change in the variables studied but also moderate-to-large magnitudes of those effects. Similar results were achieved in different studies using experienced teachers [37], which suggests that PSTs are using each teaching approach appropriately.

Despite the literature on the experiences of PSTs in teaching SE identifying certain challenges such as the omission of vital aspects of the model $[58,59]$ or problems in encouraging students to work [83], the outcomes of this study suggest that PSTs who taught SE were able to create favorable conditions for the development of empowerment and self-confidence. These results highlight the effectiveness of the PETE program that the PSTs attended, which takes into account Curtner-Smith's [61] recommendations of providing practical experiences, as learners and teachers, with different approaches and teaching models, supervised by experienced teachers.

We can note several strengths within the current study. First, teacher fidelity to teach each of the models was measured and reported. Second, it utilized a large sample at different schools. Third, the SE season's length exceeded the recommendation as appropriate for a high school SE season [21]. However, research has shown that programs regarding social and emotional learning need to be ongoing and adopt a multi-year approach. Thus, in reinforcing the suggestions of past reviews [36,84-86], future research should adopt more longitudinal data collection protocols, involving multiple seasons/units.

This research suggests the suitability of the SE in PE classes but is not without limitations. In order to reduce the "teacher effect" that may occur when different teachers 
teach different instructional approaches [87], future research must use the same teacher in the same grade to teach all the groups. The already formed classes in schools made difficult the random assignment of students, but should be considered a limitation of the design. Future studies might consider developing experimental studies since randomly assigning students to experimental and comparison conditions provides greater certainty that differences between groups on outcome measures result from the intervention. Another limitation is that this study was carried out in PE classes' real context decreasing the internal validity. However, the importance of ecological validity must also be considered, which consequently makes its results and conclusions relevant.

To reinforce the positive impact of different teaching models on personal and social skills, it would be important for future research to consider variables (such as responsibility, creativity, or assertiveness), that meet the best interests and needs of today's young people. Once significant improvements in empowerment and self-confidence help students tackle potential social problems they may face in their lives, future research can further explore these results with qualitative methodologies seeking additional explanations that can improve our understanding.

The results of this study provide support for SE as a viable option for providing students with new experiences, and as a feasible curricular model for teachers in order to promote empowerment and self-confidence in PE.

Author Contributions: Conceptualization, C.B., P.H. and I.M.; methodology, C.B., A.R. and I.M.; formal analysis, C.B., A.R. and I.M.; investigation, C.B. and I.M.; writing—original draft preparation, C.B., P.H. and I.M.; writing-review and editing, C.B., P.H., A.R. and I.M.; supervision, I.M.; funding acquisition, C.B. All authors have read and agreed to the published version of the manuscript.

Funding: This work was supported by the Portuguese Foundation for Science and Technology (FCT) [grant number SFRH/BD/121421/2016].

Institutional Review Board Statement: The study was conducted according to the guidelines of the Declaration of Helsinki, and approved by the Ethics Committee of the Faculty of Sport from the University of Porto (Process CEFADE 07.2018, approved on 24 March 2018).

Informed Consent Statement: Informed consent was obtained from all subjects involved in the study.

Data Availability Statement: The data presented in this study are openly available in FigShare at 10.6084/m9.figshare.13548017.

Conflicts of Interest: The authors declare no conflict of interest.

\section{References}

1. Taggart, A. The endangered species reviseted. Achper Natl. J. 1988, 131, 34-50.

2. Wright, P.; Craig, M. Tool for Assessing Responsibility-Based Education (TARE): Instrument Development, Content Validity, and Inter-Rater Reliability. Meas. Phys. Educ. Exerc. Sci. 2011, 15, 204-219. [CrossRef]

3. Hardman, K.; Murphy, C.; Routen, A.; Tones, S. World-Wide Survey of School Physical Education: Final Report; UNESCO, Ed.; UNESCO: Paris, France, 2014.

4. Coulter, M.; McGrane, B.; Woods, C. 'PE should be an integral part of each school day': Parents' and their children's attitudes towards primary physical education. Educ. 313 2020, 48, 429-445. [CrossRef]

5. Cryan, M.; Martinek, T. Youth Sport Development Through Soccer: An Evaluation of an After-School Program Using the TPSR Model. Phys. Educ. 2017, 74, 127-149. [CrossRef]

6. Fraser-Thomas, J.; Côté, J. Understanding Adolescents' Positive and Negative Developmental Experiences in Sport. Sport Psychol. 2009, 23. [CrossRef]

7. Opstoel, K.; Chapelle, L.; Prins, F.; De Meester, A.; Haerens, L.; Van Tartwijk, J.; De Martelaer, K. Personal and social development in physical education and sports: A review study. Eur. Phys. Educ. Rev. 2019. [CrossRef]

8. Beni, S.; Fletcher, T.; Ní Chróinín, D. Meaningful Experiences in Physical Education and Youth Sport: A Review of the Literature. Quest 2017, 69, 291-312. [CrossRef]

9. OECD. The Future of Education and Skills_Education 2030; OECD Publishing: Paris, France, 2018.

10. Bailey, R.; Armour, K.; Kirk, D.; Jess, M.; Pickup, I.; Sandford, R. The educational benefits claimed for physical education and school sport: An academic review. Res. Pap. Educ. 2009, 24, 1-27. [CrossRef]

11. Dyson, B.; Griffin, L.; Hastie, P. Sport Education, Tactical Games, and Cooperative Learning: Theoretical and pedagogical considerations. Quest 2004, 56, 226-240. [CrossRef] 
12. Tapps, T.; Passmore, T.; Lindenmeier, D.; Kensinger, W. High School Physical Education Student's and Experiential Learning in the Community: A Classroom Assignment. Strateg. J. Phys. Sport Educ. 2014, 27, 9-12. [CrossRef]

13. Jones, R.; Turner, P. Teaching coaches to coach holistically: Can Problem-Based Learning (PBL) help? Phys. Educ. Sport Pedagog. 2006, 11, 181-202. [CrossRef]

14. Mosston, M.; Ashworth, S. Teaching Physical Education, 6th ed.; Benjamin Cummings: Boston, MA, USA, 2008.

15. Moy, B.; Renshaw, I.; Davids, K. The impact of nonlinear pedagogy on physical education teacher education students' intrinsic motivation. Phys. Educ. Sport Pedagog. 2016, 21, 517-538. [CrossRef]

16. Rink, J. Teaching Physical Education for Learning; Mosby: St. Louis, MI, USA, 1993.

17. Rosado, A.; Mesquita, I. Melhorar a aprendizagem optimizando a instrução. In Pedagogia do Desporto; Rosado, A., Mesquita, I., Eds.; Edições FMH—UTL: Lisboa, Portugal, 2009; pp. 69-130.

18. Rosenshine, B. Content, time and direct instruction. In Research on Teaching: Concepts, Findings and Implications; Peterson, P., Walberg, H., Eds.; Mccutchan: San Pablo, CA, USA, 1979.

19. Reeve, J.; Lee, W. Students' classroom engagement produces longitudinal changes in classroom motivation. J. Educ. Psychol. 2014, 106, 527-540. [CrossRef]

20. Ennis, C. What goes around comes around... or does it? Disrupting the cycle of traditional, sport-based physical education. Kinesiol. Rev. 2014, 3, 63-70. [CrossRef] [PubMed]

21. Siedentop, D.; Hastie, P.; Van der Mars, H. Complete Guide to Sport Education, 2nd ed.; Human Kinetics: Champaign, IL, USA, 2011.

22. Metzler, M. Instructional Models for Physical Education, 3rd ed.; Holcomb Hathaway Publishers: Scottsdale, AZ, USA, 2017. [CrossRef]

23. Brady, F. A Theoretical and Empirical Review of the Contextual Interference Effect and the Learning of Motor Skills. Quest 1998, 50, 266-293. [CrossRef]

24. Silverman, S. Research on Teaching in Physical Education. Res. Q. Exerc. Sport 1991, 62, 352-364. [CrossRef]

25. Bartholomew, K.; Ntoumanis, N.; Thøgersen-Ntoumani, C. A review of controlling motivational strategies from a selfdetermination theory perspective: Implications for sports coaches. Rev. Sport Exerc. Psychol. 2009, 2, 215-233. [CrossRef]

26. Light, R.; Harvey, S.; Mouchet, A. Improving 'at-action' decision-making in team sports through a holistic coaching approach. Sport Educ. Soc. 2014, 19, 258-275. [CrossRef]

27. Litchfield, B.; Dempsey, J. Authentic Assessment of Knowledge, Skills, and Attitudes. New Dir. Teach. Learn. 2015, 2015, 65-80. [CrossRef]

28. Chandler, T.; Mitchell, S. Reflections on models of games education. J. Teach. Phys. Educ. 1991, 14, 467-477. [CrossRef]

29. Bunker, D.; Thorpe, R. A Model for the Teaching of Games in Secondary Schools. Bull. Phys. Educ. 1982, 18, 5-8.

30. Hellison, D. Teaching Personal and Social Responsability through Physical Activity, 3rd ed.; Human Kinectics: Champaign, IL, USA, 2011.

31. Hattie, J. Visible Learning for Teachers: Maximizing Impact on Learning; Routledge: New York, NY, USA, 2012. [CrossRef]

32. Mesquita, I. Perspetiva construtivista da aprendizagem no ensino do jogo. In Jogos Desportivos: Formação e investigação; Nascimento, J., Ramos, V., Tavares, F., Eds.; Coleção Temas Movimento: Florianópolis, Brazil, 2013; pp. 103-132.

33. Siedentop, D. What is Sport Education and how does it work? J. Phys. Educ. Recreat. Danc. 1998, 69, 18-20. [CrossRef]

34. Siedentop, D. Sport Education: Quality PE through positive sport experiences; Human Kinetics: Champaingn, IL, USA, 1994.

35. Mesquita, I.; Farias, C.; Hastie, P. The impact of a hybrid Sport Education-Invasion Games Competence Model soccer unit on students' decision making, skill execution and overall game performance. Eur. Phys. Educ. Rev. 2012, 18, 205-219. [CrossRef]

36. Araújo, R.; Mesquita, I.; Hastie, P. Review of the status of learning in research on Sport Education: Future research and practice. J. Sports Sci. Med. 2014, 13, 846-858. [PubMed]

37. Bessa, C.; Hastie, P.; Araújo, R.; Mesquita, I. What do we know about the development of personal and social skills within the Sport Education Model: A systematic review. J. Sports Sci. Med. 2019, 18, 812-829.

38. Adams, R. Empowerment, Participation and Social Work, 4th ed.; Palgrave Macmillan: New York, NY, USA, 2008.

39. Stankov, L.; Morony, S.; Lee, P. Confidence: The best non-cognitive predictor of academic achievement? Educ. Psychol. 2014, 34. [CrossRef]

40. Moore, E.W.G.; Fry, M.D. Physical Education Students' Ownership, Empowerment, and Satisfaction With PE and Physical Activity. Res. Q. Exerc. Sport 2017, 88, 468-478. [CrossRef]

41. O'Sullivan, M. PETE Academics as public intellectuals and activists in a global teacher education context. Phys. Educ. Sport Pedagog. 2018, 23, 536-543. [CrossRef]

42. Rovegno, I.; Kirk, D. Articulations and Silences in Socially Critical Work on Physical Education: Toward a Broader Agenda. Quest 1995, 47, 447-474. [CrossRef]

43. Sinelnikov, O.; Hastie, P. Teaching sport education to Russian students: An ecological analysis. Eur. Phys. Educ. Rev. 2008, 14, 203-222. [CrossRef]

44. Deem, R.; Gilroy, S. Physical Activity, Life-long Learning and Empowerment—Situating Sport in Women's Leisure. Sporteducation Soc. 1998, 3, 89-104. [CrossRef]

45. Gil-Arias, A.; Harvey, S.; Cárceles, A.; Práxedes, A.; Del Villar, F. Impact of a hybrid TGfU-Sport Education unit on student motivation in physical education. PLoS ONE 2017, 12. [CrossRef] [PubMed]

46. Hastie, P.; Buchanan, A. Teaching Responsibility Through Sport Education: Prospects of a Coalition. Res. Q. Exerc. Sport 2000, 71, 25-35. [CrossRef] [PubMed] 
47. Romar, J.; Sarén, J.; Hastie, P. Athlete-Centred coaching using the Sport Education model in youth soccer. J. Phys. Educ. Sport 2016, 16, 380-391.

48. MacPhail, A.; Kirk, D.; Kinchin, G. Sport Education: Promoting Team Affiliation Through Physical Education. J. Teach. Phys. Educ. 2004, 23, 106-122. [CrossRef]

49. Ang, S.; Penney, D. Promoting Social and Emotional Learning Outcomes in Physical Education: Insights from a School-Based Research Project in Singapore. Asia-Pac. J. Healthsport Phys. Educ. 2013, 4, 267-286. [CrossRef]

50. Bessa, C.; Hastie, P.; Ramos, A.; Mesquita, I. What Actually Differs between Traditional Teaching and Sport Education in Students Learning Outcomes? A Critical Systematic Review. J. Sports Sci. Med. 2021, 20, 110-125.

51. Viciana, J.; Casado-Robles, C.; Pérez-Macías, L.; Mayorga-Vega, D. A Sport Education teaching unit as a citizenship education strategy in physical education. A group-randomized controlled trial. Retos Nuevas Perspect. De Educ. Físicadeporte Y Recreación 2020, 38, 44-52. [CrossRef]

52. Wallhead, T.; Garn, A.C.; Vidoni, C. Effect of a Sport Education Program on Motivation for Physical Education and Leisure-Time Physical Activity. Res. Q. Exerc. Sport 2014, 85, 478-487. [CrossRef]

53. Cuevas, R.; García-López, L.M.; Serra-Olivares, J. Sport Education Model and self-determination theory: An intervention in secondary school children. Kinesiology 2016, 48, 30-38. [CrossRef]

54. Wallhead, T.; Ntoumanis, N. Effects of a Sport Education Intervention on Students' Motivational Responses in Physical Education. J. Teach. Phys. Educ. 2004, 23, 4-18. [CrossRef]

55. Hastie, P.; Sinelnikov, O.; Wallhead, T.; Layne, T. Perceived and actual motivational climate of a mastery-involving sport education season. Eur. Phys. Educ. Rev. 2014, 20, 215-228. [CrossRef]

56. Montero-Carretero, C.; Barbado, D.; Cervelló, E. Predicting Bullying through Motivation and Teaching Styles in Physical Education. Int. J. Environ. Res. Public Health 2019, 17, 87. [CrossRef] [PubMed]

57. Kinchin, G.; Penney, D.; Clarke, G. Sport education in teacher education. In Sport Education in Physical Education: Research-Based Practice; Penney, D., Clarke, G., Quill, M., Kinchin, G.D., Eds.; Routledge: London, UK, 2005; pp. 217-228.

58. Curtner-Smith, M.; Hastie, P.; Kinchin, G. Influence of occupational socialization on beginning teachers' interpretation and delivery of sport education. Sporteducation Soc. 2008, 13, 97-117. [CrossRef]

59. McCaughtry, N.; Sofo, S.; Rovegno, I.; Curtner-Smith, M. Learning to teach sport education: Misunderstandings, pedagogical difficulties, and resistance. Eur. Phys. Educ. Rev. 2004, 10, 135-155. [CrossRef]

60. MacPhail, A.; Tannehill, D.; Goc Karp, G. Preparing physical education preservice teachers to design instructionally aligned lessons through constructivist pedagogical practices. Teach. Teach. Educ. 2013, 33, 100-112. [CrossRef]

61. Curtner-Smith, M. Preparing preservice physical education teachers to teach sport education. In Sport Education: International Perspectives; Hastie, P.A., Ed.; Routledge: London, UK, 2012; pp. 151-165.

62. O'Sullivan, M. Student Learning in Physical Education: Applying Research to Enhance Instruction. In Learning to Teach Physical Education; Silverman, S., Ennis, C.D., Eds.; Human Kinetics: Champaign, IL, USA, 2003; pp. 257-294.

63. Penney, D.; Clarke, G.; Quill, M.; Kinchin, G.D. Sport Education in Physical Education: Research Based Practice; Routledge: London, UK, 2005.

64. Siedentop, D.; Tannehill, D. Developing Teaching Skills in Physical Education, 4th ed.; Mayfield Publishing Company: Mountain View, CA, USA, 2000.

65. Hastie, P.; Calderón, A.; Rolim, R.; Guarino, A. The development of skill and knowledge during a Sport Education season of track and field athletics. Res. Q. Exerc. Sport 2013, 84, 336-344. [CrossRef]

66. Spreitzer, G. Psychological empowerment in the workplace: Dimensions, measurement, and validation. Acad. Manag. J. 1995, 38, 1442-1465. [CrossRef]

67. Santos, J.; Gonçalves, G.; Orgambídez-Ramos, A.; Borrego-Ales, Y.; Mendoza-Sierra, I. Adaptação da escala de Empowerment Psicológico de Spreitzer numa amostra portuguesa. Avaliação Psicológica 2014, 13, 325-332.

68. Uner, S.; Turan, S. The Construct Validity and Validity of the Turkish Version of Spreitzer's Psychological Empowerment Scale. BMC Public Health 2010, 10, 117. [CrossRef]

69. Thomas, K.; Velthouse, B. Cognitive elements of Empowerment: An "Interpretive" Model of Intrinsic Task Motivation. Acad. Manag. Rev. 1990, 15, 666-681. [CrossRef]

70. Gist, M. Self-efficacy: Implications for organizational behavior and human resource management. Acad. Manag. Rev. 1987, 12, 472-485. [CrossRef]

71. Bell, N.; Staw, B. People as sculptors. In Handbook of Career Theory; Arthur, M., Hall, D., Lawrence, B., Eds.; Cambridge University Press: New York, NY, USA, 1989.

72. Ashforth, B. The experience of powerlessness in organizations. Organ. Behav. Hum. Decis. Process. 1989, 43, 207-242. [CrossRef]

73. Martens, R.; Burton, D.; Vealey, R.; Bump, L.; Smith, D. Development and validation of the Competitive State Anxiety Inventory-2. In Competitive Anxiety in Sport; Martens, R., Ed.; Human Kinetics: Champaing, IL, USA, 1990; pp. 127-140.

74. Vasconcelos-Raposo, J. Diferenças por Classificação no Nível de Ansiedade Cognitiva, somática e Auto-Confiança; UTAD: Vila Real, Portugal, 1995.

75. Gabilondo, J.A.; Rodríguez, O.; Moreno, M.; Galarraga, S.; Cecchini, J. Validation of the competitive state anxiety inventory 2 (CSAI-2 re) through a web application. Revista Internacional De Medicina Y Ciencias De La Actividad Fisica Y Del Deporte 2012, $12,539-556$. 
76. Zumbo, B. Validity: Foundational Issues and Statistical Methodology. Handb. Stat. 2007, 26, 45-79. [CrossRef]

77. Field, A. Discovering Statistics Using IBM SPSS Statistics; SAGE: Newbury Park, CA, USA, 2013.

78. Cohen, J. Statistical Power Analysis for the Behavioral Sciences; Routledge: New York, NY, USA, 1988. [CrossRef]

79. Nunnally, J.; Bernstein, I. Psychometric Theory; McGraw-Hill, Inc.: New York, NY, USA, 1994.

80. Spittle, M.; Byrne, K. The influence of Sport Education on student motivation in physical education. Phys. Educ. Sport Pedagog. 2009, 14, 253-266. [CrossRef]

81. Burgueño, R.; Medina-Casaubón, J.; Morales-Ortiz, E.; Cueto-Martín, B.; Sánchez-Gallardo, I. Sport Education versus Traditional Teaching: Influence on motivational regulation in High School students. Cuadernos de Psicologia Del Deporte 2017, 17, 87-89.

82. Burgueño, R.; Cueto-Martín, B.; Morales-Ortiz, E.; Silva, P.; Medina-Casaubón, J. Clarifying the influence of sport education on basic psychological need satisfaction in high school students. Motricidade 2018, 14, 48-58. [CrossRef]

83. McMahon, E.; Macphail, A. Learning to teach Sport Education: The experience of a pre-service teacher. Eur. Phys. Educ. Rev. 2007, 13, 229-246. [CrossRef]

84. Hastie, P.; Martinez de Ojeda, D.; Calderón, A. A review of research on Sport Education: 2004 to the present. Phys. Educ. Sport Pedagog. 2011, 16, 103-132. [CrossRef]

85. Ko, B.; Wallhead, T.; Ward, P. Chapter 4: Professional development workshops-What do teachers learn and use? J. Teach. Phys. Educ. 2006, 25, 397-412. [CrossRef]

86. Wallhead, T.; O'Sullivan, M. Sport Education: Physical education for the new millenium? Phys. Educ. Sport Pedagog. 2005, 10, 181-210. [CrossRef]

87. Browne, T.; Carlson, T.; Hastie, P. A comparison of rugby seasons presented in traditional and Sport Education formats. Eur. Phys. Educ. Rev. 2004, 10, 199-214. [CrossRef] 